\title{
The Impact of the Electoral System on the Independence and Efficiency of the Jordanian House of Representatives
}

\author{
Hazem Suleiman Toubat \\ Assistant Professor \\ School of Law \\ Jadara University \\ Irbid, Jordan. \\ Emran Mahafzah \\ Associated Professor \\ Jadara University \\ School of Law \\ Irbid, Jordan. \\ Hashim Ahmed Balas \\ Jordanian Bar Association
}

\begin{abstract}
This study aims to examine critically the impact of the electoral system adopted in Jordan on the independence and efficiency of the House of Representatives in carrying out the constitutional functions assigned to it. The historical approach was adopted in this study in addition to the doctrinal approach. The study concludes that the temporary election laws issued by the Government. Which are based on "One Man, One Vote System" have negatively affected the efficiency and independence of the House of Representatives. It has disrupted the activities and role of the political parties, then weakened the House of Representatives, and makes it an easy tool in the hand of the Government. Therefore, the House of Representatives does not achieve its supposed function in the legislation and overseeing the government's actions. The study recommends the adoption of the Open-List System in the parliamentary elections because it is closer to the democratic approach.
\end{abstract}

Keywords: Electoral System, House of Representative, Jordanian Parliament.

\section{Introduction}

The House of Representatives in Jordan is part of the National Assembly, which also consists of the Senate, whereas the National Assembly and the King constitute the Legislative Authority. The House of Representatives is a council elected by the people by direct and secret ballot based on an electoral system adopted by the election law, while the senators are appointed by the king. The House of Representatives differs from the Senate that the Senate performs only the function of legislation, whereas the House of Representatives is tasked with overseeing the government's actions alongside the legislation.

The electoral system by which the parliamentary elections were conducted was influenced by the political and regional circumstances experienced by the Jordanian state, and that the elections were held in accordance with different and changing election laws in each parliamentary election. These changing laws affected the nature of the Council's composition and thus the efficiency and independence of the successive Houses of Representatives.

This study aims to examine the impact of the electoral system adopted in the elections of the parliamentary council on its independence and efficiency in carrying out the constitutional functions assigned to it. Achieving this goal requires the evolution of parliamentary life in Jordan and the circumstances that accompany the elections of Parliament.

\section{Parliamentary Life in Jordan from 1947- 1989}

Parliamentary life began after Jordan gained independence from Britain in 1946, where the first parliamentary elections were held in 1947 (Jordanian Parliament, Official Website). Among the resolutions adopted by this Council was the unity of the two Banks of the Jordan River after the Arab defeat in the Arab-Israeli War of 1948. 
In April 1950, following the unification of the Banks of the Jordan River, the second parliamentary elections were held in both Banks after the amendment of the election law to include constituencies representing the West Bank, bringing the total number of deputies to 40 members equally between the West and East Bank(Jordanian Parliament, Official Website). The Parliament lasted for one year only. It was dissolved due to the absence of cooperation between the Legislative and Executive Authorities. In October 1951, elections were held to elect the Third House of Representative, which continued until June 1954. This Council was dissolved due to its opposition to government policy and lack of cooperation with the Executive Authority (Jordanian Parliament, Official Website).

In November 1954, the fourth parliamentary elections took place in an atmosphere of violent demonstrations that resulted in the deaths of several citizens. These events forced the Prime Minister, Tawfiq Abu Huda, to resign, to be followed by a new Government headed by Saeed AL-Mufti. The new Government soon resigned because of the controversy overwhelming the Baghdad Pact." After this, a new Government was formed. This Government also resigned because of strong popular opposition, due to the government's declaration of its desire to enter Baghdad Pact, where the political parties and other political forces played a major role in the participation and attract the masses. Subsequently, a new government was formed, and Parliament was dissolved in December 1955(Mahafzah, 2013).

In 1956, the election of the Fifth House of Representative was conducted, which was the first fair and acceptable elections. This Council was elected on the basis of party blocs. The late King Hussein tasked to Suleiman Al Nabulsi to form a new Government by virtue of the fact that he was the general secretary of the political party that gained the majority. This Government is the only Government in the history of Jordan not to have been appointed by the King, where, the formation of the Government in this way was contrary to what is usual, as the King who appoints the Government (Mahafzah, 2013).

The Government terminated the Jordanian-British Treaty on March 13, 1957, and replaced British aid with Arab financial aid from Egypt, Saudi Arabia, and Syria. It also rejected the Eisenhower Doctrine*. This Government was not compatible with the King's trends, and therefore, the Government was dismissed on 10 April 1957, six months after its formation. Subsequently, martial law was declared, leading to the abolition of political parties and the banning of their activities, as well as the formation of governments returned as usual where the King chooses the Prime Minister (Mahafzah, 2013).

In 1961, the Sixth Parliament was elected, but it did not complete its constitutional term.It was dissolved in 1962 by the King for lack of cooperation between the Government and the Parliament. The same fate happened to the Seventh and Eighth Parliament where the Seventh Parliament lasted only one year and the Eighth Parliament lasted 3 years (Ministry of Political and Parliamentary Affairs in Jordan, Official Website).

The ninth parliamentary elections were held before the June 1967 Arab-Israeli War, which resulted in the occupation of the West Bank. Following the occupation of the West Bank, the Arab Summit was held in Morocco on October 16, 1974 and issued a resolution recognizing the Palestine Liberation Organization as the sole legal representative of the Palestinian people and approving the establishment of a Palestinian Government in the West Bank after the end of the Israeli occupation (Jordanian Parliament, Official Website). Due to these events, the election of a new Parliament which was supposed to be held in 1971was not achieved. Consequently, the King issued a Royal Decree, extending the Ninth Parliament's term for another 2 years; however, the Ninth Parliament continued to exercise its functions until it was dissolved on November 23, 1974(Jordanian Parliament, Official Website). From 1974 to 1984, parliamentary life in Jordan completely stalled; however, in 1978, King Hussein formed the National Consultative Council, which was mandated to study and discuss all draft laws and to give opinions and advice to the Council of Ministers prior to their approval.

\footnotetext{
* "The Baghdad Pact is one of the Cold War period alliances. It was established in 1955 to counter the Communist tide in the Middle East and was formed from the United Kingdom, Iraq, Turkey, Iran, and Pakistan. The United States of America was the initiator of the idea of establishing this Pact, where it promised economic and military assistance to the members, but did not participate directly in it. Where the Jordanian people and some ministers had believed that this Pact is an imperialist alliance created by the Western colonial powers and had declared goals to address the Communist tide and the hidden goals of supporting the State of Israel - control of the oil sources - hit the liberation movements".

${ }^{*}$ President Dwight D. Eisenhower announced the Eisenhower Doctrine in January 1957, and Congress approved it in March of the same year. Under the Eisenhower Doctrine, a country could request American economic assistance and/or aid from U.S. military forces if it was being threatened by armed aggression from another state. Eisenhower singled out the Soviet threat in his doctrine by authorizing the commitment of U.S. forces "to secure and protect the territorial integrity and political independence of such nations, requesting such aid against overt armed aggression from any nation controlled by international communism." (Office of the Historian. The Eisenhower Doctrine, 1957.https://history.state.gov/milestones/1953-1960/eisenhower-doctrine
} 
The National Consultative Council was formed in accordance with a temporary law, whereby its members were appointed by the King and included figures from various ideological and partisan trends, including former members of Parliament and governments. This Council continued his work until 1984 through 3 sessions, each session lasting 2 years(Ministry of Political and Parliamentary Affairs in Jordan, Official Website) On January 7, 1984, the King issued a Royal Decree inviting the Ninth Parliament to meet in extraordinary session from 9 to 16 January 1984. At this session, the Constitution was amended to make it possible for the King to restore the dissolved Council and invite it to convene. Another constitutional amendment also carried out at that session allowed the holding of parliamentary elections in some constituencies if it could not be held in all constituencies, and then the elected members selected the other members of the constituencies in which elections could not be held.

Based on these amendments, the King issued a Royal Decree to resume parliamentary life after a 10-year break, in which, the members of the Ninth House of Representative who were elected in 1974 were brought back to the Council and continued their function until 1989, under the name of the Tenth House of Representative(Jordanian Parliament, Official Website).

In 1988, a decision was made to disengage the West Bank from Jordanian sovereignty and placed under the responsibility of the Palestine Liberation Organization. Under this decision, it became possible to hold parliamentary elections in the East Bank only (Ministry of Political and Parliamentary Affairs in Jordan, Official Website).

The suspension of parliamentary life for more than 10 years led to the absence of popular participation and parliamentary oversight of government actions. Consequently, the Government monopolized the decision-making and drawing up of economic policies, which negatively affected the living conditions of citizens; prices soared, corruption spread, and unemployment rate rose. These negative effects prompted the people to demonstrate and protest (Khaberni News Website, April 18, 2011).

\section{Parliamentary Life in Jordan from 1989- 2019}

In April 1989, Jordan witnessed protests and demonstrations. The demonstrations were the result of the country's poor economic conditions, as well as the government's decision to raise prices (Jarrar, November 15, 2015).However, these demonstrations quickly turned into a demand for public freedom, toppling the Government and allowing parties to exercise political activities. Therefore, it was necessary to engage in a new political phase, based on a democratic approach and political openness (Khaberni News Website, April 18, 2011). As a result, the Government headed by Zaid al-Rifaiwas dismissed and a new Government headed by Prince Zeid bin Shaker was appointed. This Government abolished the emergency law in force since 1957 and allowed the political parties to practice political activities, and then it hold parliamentary elections to elect The Eleventh House of Representative in 1989(Al-Wadaan, 2011).

The Eleventh House of Representative consisted of 80 deputies, representing the various constituencies in Jordan, which was elected from several political, partisan, and ideological categories. The elections were held under the Election Law No. 22 of 1986, which allowed voters to elect a number of candidates equal to the number of deputies assigned to his constituency, which is named "Open-List System"(Ministry of Political and Parliamentary Affairs in Jordan, Official Website).The advantage of this law is that it allows voters to vote for candidates on the basis of tribal, ideological, and partisan at the same time. Therefore, this law served the political and ideological parties. This Law showed a serious desire to go to democracy, which resulted in the election of a strong and independent Parliament with strong partisan representation.

In 1993, the Executive Authority dissolved the House of Representatives 5 months before the end of its constitutional term, and then issued the Temporary Election Law No. 15 of 1993, known as the law of "One Man, One Vote." It replaced the "Open List System" with a new system that restricts the voter to electing only one candidate, regardless of the number of seats assigned to his constituency. The Law based on "One Man, One Vote System" coincided with new election constituencies' regulation, which explains the electoral map in Jordan. Many opponents argue that the Government divides electoral districts in favor of rural and tribal areas at the expense of urban areas, where the opposition political parties usually receive more support(Jeremy, 2015).

On October 8, 1993, the election of the Twelfth House of Representative was held for the first time under a temporary law, and was based on the "One Man, One Vote System." Thereafter, successive parliamentary elections have been held in accordance with laws based on this system. In the period of the Twelfth House of Representative, the JordanIsrael Peace Treaty was signed and ratified. In November 1997, the thirteenth parliamentary elections were held in accordance with Temporary Election Law No. 24 of 1997, which amended the schedule annexed to the original law on the division of constituencies. The voting percentage was $54.4 \%$ of the total number of voters registered in the voter's lists (Ministry of Political and Parliamentary Affairs in Jordan, Official Website), where some political parties boycotted the elections (Hammouri, 2010). 
After the Thirteenth House of Representatives ended its constitutional term, the King issued a Royal Decree to postpone parliamentary elections for two years, where this council was dissolved on July 16, 2001 and the elections of the Fourteenth House of Representatives were held on June 17, 2003 (Ministry of Political and Parliamentary Affairs in Jordan, Official Website). During this period, the Government issued 220 temporary laws, including the Temporary Election Law No. 34 of 2001(Hammouri, 2010).

The election of the Fifteenth House of Representative was held in 2007, in accordance with the Temporary Election Law No 34 of 2007, which based on a "One Man, One Vote System." These elections have been raised doubts about the integrity, where the Government prohibited non-governmental organizations from monitoring the elections. After the elections of 2007, people lost confidence in the Government and in the House of Representatives produced by the elections. The majority of people were convinced that the election was rigged by the Government. This conviction of rigging the elections resulted in the reluctance of citizens to participate in the electoral process.

The elections of the Sixteenth House of Representatives were also held in 2010 in accordance with the Temporary Election Law No. 9 of 2010, which based on the policy of "One Man, One Vote System." The Council continued for 2 years, where it was dissolved in 2012 because of the 2011 constitutional amendment (Jordanian Parliament, Official Website).

The elections of the Seventeenth House of Representatives were held in 2013, under the supervision of the Independent Election Commission, established in accordance with the 2011 constitutional amendment. The elections were held based on a "One Man, One Vote System." Popular participation in these elections had been remarkably low.

In 2016, the current Parliament was elected in accordance with an election law based on the principle of "One Man, One Vote System" with minor changes that did not affect its essence(CNN, September 23, 2016)This Parliament has not changed much from the previous Parliaments in terms of the weight of the opposition(Al-Dhib, October 30, 2016). The opposition in current Parliament is represented by the National Coalition for Reform, which includes 16 deputies out of 150 deputies. This is not a large number, however, their presence gives the Parliament more political flavour and increases or improves discussions within Parliament, but it cannot influence any decision taken by the council(.Beiter, September 25, 2016).

\section{Discussion and Analysis}

A review of the circumstances of the Parliamentary elections in Jordan revealed that there are some factors that affected the independence and the efficiency of Parliament. The most prominent of these factors is that most of the parliamentary elections were conducted in accordance with temporary election laws issued by the Government. Furthermore, these election laws are based on "One Man, One Vote System". These laws negatively affected the performance of the House of Representatives and its independence, where these laws meet the will of the Government and do not take into account the actual representation of the people.

The 1989 parliamentary elections, which was held under "Open-List System", were an example of true democracy, impartiality, and neutrality (Al-Wadaan, 2011). These elections revealed the weight of the opposition political parties, their popularity and their ability to influence the political decision. It is considered the best among all elected parliaments since then (Mahafzah, 2013).It played its real role in the function of supervision and legislation, without the Executive Authority having any role in directing or controlling it (Mahafzah, 2013).

However, following the dissolution of the Eleventh House of Representatives, the Government issued the Temporary Election Law of 1993, based on a "One Man, One Vote System" to replace the Open List System. Under the provisions of this law, the twelfth parliamentary elections in 1993 were held. The election of the House of Representatives is not an emergency matter requiring the issuance of a temporary law whereby the holding of the parliamentary elections, where there is a valid election law based on the "Open List System"; under its provisions, the Eleventh House of Representatives elections were held.

The election law that based on "One Man, One Vote System" has largely devoted tribalism and government control on the House of Representatives; when the voter is forced to choose only one candidate, he will typically choose the candidate based on tribal or familial ties, not on partisan or ideological. Meaning that, this system aims at reaching the individual deputy rather than the partisan deputy to Parliament. The individual deputies can be easily controlled and directed by the Executive Authority.

Moreover, most of them are businesspersons who do not have sufficient legal and constitutional experience, where, their main goal is to obtain personal interests or interests related to their constituencies at the expense of their legislative and supervisory role. They also do not have partisan programs seeking to achieve them, or partisan reference to provide them with the necessary advice. 
Consequently, they do not have the competence required to discuss public affairs or to evaluate the laws to be voted upon for approval, where their voting in Parliament depend on the achievement of their personal and private interests. On the other hand, the attitude of the party deputies depends on the attitude of the party to which he belongs and thus becomes difficult to be controlled and guided.

\section{Conclusion}

The election laws, which are based on "One Man, One Vote System" are considered a setback in the Jordanian parliamentary life. It has disrupted the activities and role of the political parties, then weakened the House of Representatives, and makes it an easy tool in the hand of the Government. This Law led to the election of parliamentarians based on tribal, rather than partisan bases. Therefore, the Jordanian houses of representative do not represent the people's ambition, and could not oppose the decisions or directions of the Government. They had no role in the legislation process except the ratification of the draft laws issued by the Government as an essential constitutional procedure, without practicing a significant role in changing the legal provisions. Accordingly, the role of Parliament in the enactment of laws is merely a formality that is not effective, and the actual power of legislation is the Executive Authority. The study recommends a return to the "Open- List System in the parliamentary elections that were adopted in the 1989 elections, as this system enshrines the democratic approach based on party participation.

\section{References}

Alaa Al-Dhib. (October 30, 2016). A Weak Opposition in the Eighteenth Council. Saraya News. https:// www. sarayanews.com/article/394717.

Al-Wadaan, Hail. (2011). "The Impact of Democratic Transformation in the Relationship between the Legislative Branch and the Executive Branch of the Jordanian Political System (1989-1997).” Jordan Journal of Social Sciences 4, no. 3. 320-337.

Beiter, Katie. (September 25, 2016).The Results Are In! Jordan has a New Parliament. The Media Line..http:/ /www .themedialine.org/news/results-jordan-new-parliament/

CNN. (September 23, 2016). Elections of Jordan. The Return of Islamists to Parliament and the Survival of Tribal Weight and Increase the Share of Women. https://arabic.cnn.com/middleeast/2016/09/23/jordan-electionsresults.

Jarrar, Shaker. (November 15, 2015). Between April and October: The Transformations of the Jordanian State, https://www.7iber.com/politics-economics/on-november2012-protests/.

Jeremy M. Sharp. (2014).Jordan: Background and US Relations. Diane Publishing.

Hammouri, Mohammad. (2010).. Rights and Freedoms between Political Whims and Constitutional Requisites, the Case of Jordan, (Amman: Dar Wael for publication.

Khaberni News Website. (April 18, 2011). Names in the Memory of April. https://www.khaberni.com/ news/ 53286.

Mahafzah, Ali. (February 25, 2013). Parliamentary Government in Jordan. Website of Ammon News,. Available at: http://www.ammonnews.net/article/145948.

Official Website of the Jordanian Parliament, Parliamentary Life (1946- 1974). ttp://www .parliament. jo/ en / node/147.

Official Website of the Ministry of Political and Parliamentary Affairs. https://jordan. gov.jo/wps/ portal/ Home\#/. 